\title{
改良円錐孔底法による地山応力測定
}

\author{
小 林 昭 一* 高 橋 徹**

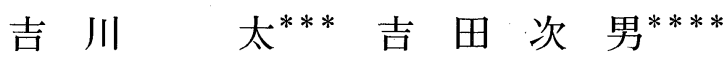

\section{Initial Rock Stress Measurement by Use of an Improved Conical-End Borehole Method}

by

\author{
Shoichi KobaYaShI ${ }^{*}$, Tohru TaKaHASHI ${ }^{* *}$, Tohru YoshiKaWA ${ }^{* * *}$ and Tsuguo YoshidA ${ }^{* * * *}$
}

\begin{abstract}
The present paper describes an improved Conical-End Borehole Method (ImCEBM) and its field application to initial rock stress measurement. The ImCEBM is an improved version of the Conical-End Borehole Method (CEBM). The improvements are made such ways as 1) an inspection borehole is bored ahead of the conical-end borehole, 2) the samediameter overcoring as that of the borehole is done. By use of the Fast Multipole Boundary Element Method (FMBEM), simulation of the overcoring was made and strains induced by overcoring are obtained. Using the strains, the conversion matrix from measured strains to initial rock stresses was determined. Field measurements were successfully carried out at a site of sandy shale and of fine-grained sandstone, respectively. Initial compressive principal stresses are, for example, 36,12 and $7 \mathrm{MPa}$, respectively directed in $\mathrm{N} 100^{\circ} \mathrm{E}$ and horizontal, $\mathrm{N} 10^{\circ} \mathrm{E}$ and $60^{\circ}$ declined from the vertical, and $\mathrm{N} 160^{\circ} \mathrm{W}$ and $30^{\circ}$ declined from the vertical.
\end{abstract}

Key words : Initial rock stress, Improved conical-end borehole method, FMBEM simulation, Field measurement

\section{1 はじめに}

地下構造物を合理的に設計するためには，前もって地 山の初期応力状態を把握しておくことが必須である。従 来から, 幾多の初期応力測定法が提案され，試みられて きたが,1,2)なかでもボアホールを利用した応力解放法は 信頼性の高い方法として認められている.1), 2) そのような 応力解放法の一つとして, 円錐孔底ひずみゲージ法 （CEBM：ボーリング孔底を円錐状に仕上げ，円錐面に ひずみゲージをセットしたプラグを接着した後, ボアホ 一ル全体をオーバーコアすることにより生じた開放ひず みから，一孔のみを用いて地山の初期応力状態を推定す る方法）が提案され，現位置試験によりその有効性が確 認された. ${ }^{4), 5)}$ その後, さらに円錐孔底の先方に探査細孔 を穿ち, ボアホール周辺の岩の状態を把握するアイデア が提案された.6. なお， 円錐孔底法に関しては，文献 ${ }^{7)} も$ 参照されたい。

この論文は，CEBM 法をさらに改良した効率的な方法 （改良円錐孔底法 (ImCEBM) と呼ぶことにする）を提案 し，その有効性を現位置試験によって確認した結果を述 べたものである.

改良はつぎのようである。

（1） 円錐孔底の先端に岩盤状態を探査するための細孔 （探查細孔）を穿った。

(2) 応力解放のためのオーバーコアリングをボアホー 儿径と同径で行った（同径オーバーコアリング）.

(3) オーバーコアリング中に解放ひずみの計測を可能 とした.
この論文の前半では, 簡単に改良円錐孔底法とその測 定原理を述べ，オーバーコアリングによる応力解放過程 を高速多重極境界要素法 (FMBEM) を用いてシミュレ ーション解析した結果を述べ，それに基づいて，オーバ ーコアリングに伴う解放ひずみから地山初期応力を求め るための行列（変換行列）を定めた.

後半では, ある地下発電所の調查坑で実施した現位置 初期応力測定とその結果について述べた.

なお，この論文は文献 ${ }^{8)}{ }^{9}$ のシミュレーション解析法 の記述を削除して前半を整理・短縮し, 後半の現位置試 験の部分を拡充したものである.

\section{2 応力解放法による初期応力の推定}

いま，初期応力状態が未知な岩盤にボアホールを掘削 し，孔底を円錐状に仕上げて，その表面の適切な位置に ひずみゲージを接着したとする。この状態ではひずみは ゼロである。この円錐孔底周辺をオーバーコアする。そ れによる応力解放に伴って円錐孔底面上にひずみが誘起 される，岩盤を等方・線形弾性的であると仮定すると， 誘起されるひずみ（解放ひずみ）は初期応力に比例する. したがって，オーバーコアリングのある過程（深度）で 解放ひずみを計測すれば，それをもとに初期応力を求め ることができる.オーバーコアリング過程での解放ひず みはその深度に伴って変化するが, 円錐孔底周辺の初期 応力が完全に解放された（円錐孔底から十分に長くオー バーコアした）状態では，ひずみは一定值に落ち着くこ とになる。一般に, 応力開放が完了した状態での解放ひ ずみの值は大きいので，それを用いて地山初期応力を推

\footnotetext{
$\dagger$ 原稿受理 平成 14 年 8 月 6 日 Received Aug. 6, 2002

* 正 会 員 福井工業大学地球環境工学科 T910-8505 福井市学園, Dept. of Global Environ. Eng., Fukui Univ. of Tech., Gakuen, Fukui, 910-8505

** 理化学研究所情報基盤研究部 $=350-0198$ 和光市広沢, Advanced Computing Center, RIKEN, Hirosawa, Wako, 350-0198

*** 正 会 員 ニュージェック(株) †542-0082 大阪市中央区島之内, NEWJEC Co., Tyuoh-ku, Osaka, 542-0082

$* * * *$ 関西電力(制)総合技術研究所 $=661-0035$ 尼崎市若王子, Tech. Res. Inst., Kansai Power Electric Co., Nyakuohji, Amagasaki, $661-0035$
} 
定するのが普通である。

いま, 岩盤が初期応力状態

$$
\{\sigma\}^{T}=\left\{\sigma_{11}, \sigma_{22}, \sigma_{33}, \sigma_{12}, \sigma_{23}, \sigma_{31}\right\}
$$

にあるとする。 ここに, $\sigma_{i k}(i k=1,2,3)$ は直交デカルト 座標系 $\left(\mathrm{O}-x_{1} x_{2} x_{3}\right)\left(x_{1}\right.$-軸はボアホール中心軸に一致し， 奥の力向を向く）での応力成分を表す (Fig. 1 参照)。

一方, オーバーコアリングによって円錐孔底表面上に はひずみ

$$
\{\varepsilon\}^{T}=\left\{\varepsilon_{11}, \varepsilon_{12}, \sigma_{33}, \cdots \cdots, \varepsilon_{N 1}, \varepsilon_{N 2}\right\}
$$

が誘起される。ここに，最初の下添え字は円錐表面上の 测定位置（点）を，つぎの下添え字 1 および2は，それ ぞれ円錐面の母線およびそれに直交する方向を意味して いる。

岩盤は等方線形弾性体と仮定しているので，次式が成 り立つ。

$$
\{\varepsilon\}=\frac{1}{E}[A]\{\sigma\}
$$

ここに，Eはヤング率であり，係数行列はひずみ行列 $(2 \mathrm{~N} \times 6)$ と呼ばれる。

行列 $[A]$ が与光られておれば，計測した解放ひずみか ら只れを誘起した応力（地山初期応力）を求めるための 観測方程式を誘導することは容易である。

6 個以上のひずみ計測值を用い，最小二乗法を適用す ると, 式 (3)より

$$
[A]^{T}[A]\{\sigma\}=E[A]^{T}\{\varepsilon\}
$$

を得，したがって，応力はつぎのように求められる。

$$
\{\sigma\}=E[D]\{\varepsilon\}
$$

ここに

$$
[D]=\left([A]^{T}[A]\right)^{-1}[A]^{T}
$$

である。これは計測した解放ひずみから初期応力を求め るための変換行列 $(6 \times 2 \mathrm{~N})$ である。

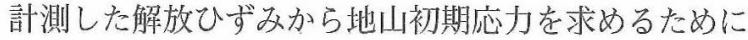
は，この変換行列を求めること，したがって，ひず多行 列 $[A]$ を求めることが鍵となる。それには，高速多重極 境界要素法 (FMBEM) が有効である。

$$
3 \text { オーバーコアリングのシミュレーション }
$$

このシミュレーションの主目的は，オーバーコアリン グの進行に伴って円錐面上に誘起されるひずみを求める ことである。

オーバーコアリング過程では円錐状の表面を円柱表面 (その高さがオーバーコアリングの進行につれて次第に高 くなる）で囲んだ形が形成されるので，シミュレーショ ン解析では只の形状を正確にモデル化することが必要で ある。またシシュレーション結果のうち後に利用する データは円錐表面のひずみだけであるので，それを正確 に求めることができる方法が望まれる。このような目的 には，境界要素法 $(\mathrm{BEM})$ が適している。特に，大規模 計算には高速多重極法 (FMM) を併用した方法，高速多 重極境界要素法 (FMBEM) が極めて有利に適用できる。

シミュレーション解析は，つぎの3 次元等方線形弾性 体の支配方程式（Navier 式）

$$
\mu \partial_{k k} u_{i}+(\lambda+\mu) \partial_{i k} u_{k}=0
$$

を与えられた境界条件のもとで解くことである。ここに， $u_{i}$ は変位の $x_{i}$-方向成分, $\lambda, \mu$ は Lame' 定数, $\partial_{i}$ は $x_{i}$ に よる偏微分を意味している。

境界条件としては，一様な単位応力が無限遠から作用 しており，またボーリングれ表面，円錐表面，探查孔表 面拉よびオーバーコアリングによって生じた表面には表 面力が作用しない（自由表面）とした。

上の境界值問題に対する積分方程式はつぎのように与 えられる。

$$
\frac{1}{2} u_{i}(x)=u_{i}^{\infty}(x)-v \cdot p \cdot \int_{S} T_{i j}(x-y) u_{j}(y) d S_{y}
$$

ここに, $S$ は上述の表面の総和，v.p.はCauchy の主值積 分である。 $T_{i j}(x-y)$ 汪基本解から導かれる表面力テンソ ル, $u_{i}^{\infty}(x)$ は無限遠から作用している単位応力によって生 じた変位成分であり，つぎのように与えられる。

$$
u_{i}^{\infty}(x)=\frac{1}{E}\left\{(1+v) \sigma_{i j}^{\infty}-v \delta_{i j} \sigma_{k k}^{\infty}\right\} x_{j}
$$

ここに, $v$ はP Poisson 比である。

この積分方程式を解いて，無限遠から作用する6個の 独立な応力成分 $\left(\sigma_{11}, \sigma_{22}, \sigma_{33}, \sigma_{12}, \sigma_{23}, \sigma_{31}\right)$ (Fig. 1 参照) によって生じる 6 組の変位成分 $\left(u_{1}, u_{2}, u_{3}\right)$ (Fig. 1 参照) が求められる。光れもとに所要のひずみを算定する。

積分方程式の解法としては, 高速多重極境界要素法が 適用される。この方法は非常に強力であり，この種の問 題には最適である。なお，高速多重極法の詳紲について

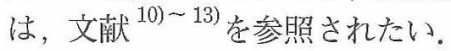

高速多重極境界要素法によるシミュレーション解析で は, 簡単のために, 弾性係数 $\mathrm{E}=1$, Poisson 比 $v=1 / 4$ の等方線形な弾性体が無限遠より単位の一様な応力を受 けている状態を想定し, 初期状態として，ボーリング孔 が掘られ，円錐孔底が形成されて，その前方に探査細孔 が仕上げら机ているものとする。解析では，ひずみゲージ を貼付することを想定して選んだ円錐表面上の点のひず み成分が，オーバーコアリングの進行に伴ってどのように 変化するかを調べることとした。なお，解析の詳細につい

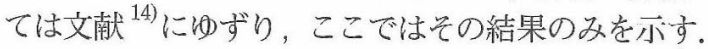

初期状態での解析モデルと境界要素分割を Fig. 1 に示 す。このモデルの幾何形状は，後に現位置試験で用いた ものと同じである。初期状態でのモデルの自由度 (DOF) は13824であった，現位置試験では開放ひずみは，Fig. 2 に示すように, 円錐表面上の 6 点で, 円錐の母線方向と それと直交する方向の合計 12 成分を計測することとし ているので，シミュレーション解析でも対応したひずみ 変化を調べることとした。な抒，改良円錐孔底法を現位 置で適用する場合には，ボアホールの長さは20〜 30m であるが，オーバーコアリングによって生じたひずみが 影響を受ける範囲は円錐孔底周辺に限られるので，解析 モデルでは孔底から後方約 $500 \mathrm{~mm}$ の範囲老考慮した。

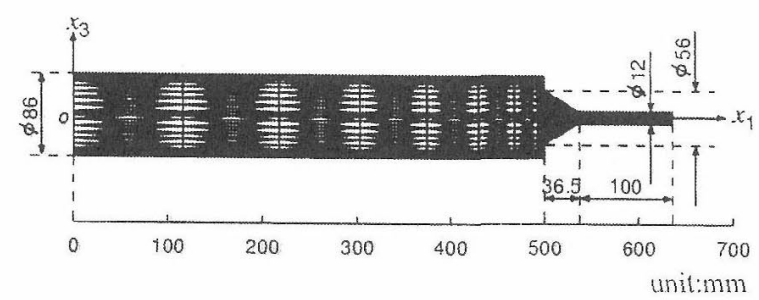

Fig. 1. ImCEBM model and its surface elements. 


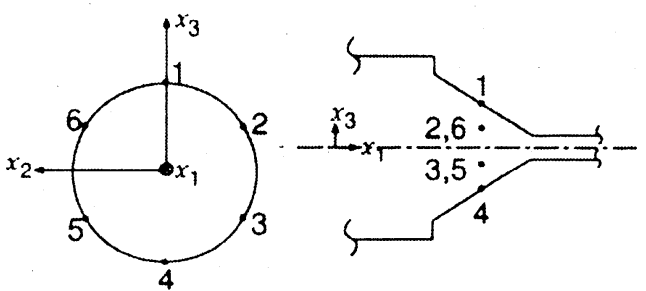

Fig. 2. Strain measuring positions.

シミュレーション解析は, オーバーコアリング深度 $L=$ 0, 7. 3，14. 6, ․ 73mm の各ステージについて行った. その際の円錐孔底周辺とオーバーコアリング孔表面の要 素分割状態を Fig. 3 に示した. 最終ステージでのモデル の自由度は 48384 であった。

Fig. 4 (a) および (b) は，無限遠から単位の（初期） 応力 $\sigma_{11}^{\infty}$ および $\sigma_{22}^{\infty}$ がそれぞれ作用している場合につい て, オーバーコアリングの進行に伴ってひずみ成分が変 化する状況を示したものである. 他の応力条件に対して も類似の結果が得られる。このようにして求めたひずみ からひずみ行列 $[A]$ が得られる。それより式 (6) の変換 行列 $[D]$ が求められる. その例を付録に示した.

なお, シミュレーション結果から判断して, 応力解放 によって誘起されたひずみはオーバーコアリング深度が ボアホール径のほぼ 70\%の深さに達するとほとんど収束 しているようである.このことから, ボアホール径程度 の長さ (深度) にオーバーコアすれば, 初期応力を推定 するには十分であろう。

\section{4 現位置測定と結果}

改良円錐孔底法の適用性を確認するために，ある地下 発電所の調査坑内で現位置試験を実施した。試験場所は 被り約 $520 \mathrm{~m}$ の 2 地点であり, 岩質はそれぞれ砂質頁岩 および細粒砂岩であった。

現位置試験では, 特に，1）探査細孔を用いた岩盤状 態の探査が測定位置選定にどのような役割を果たすか, および2) ボアホールと同径のオーバーコアリングはどの ように有効であるかを調べることに留意した。

現位置試験の手順はつぎのようである.

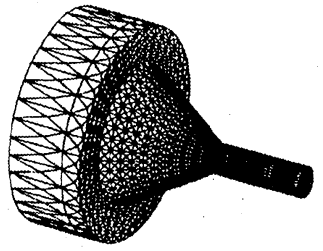

(a)

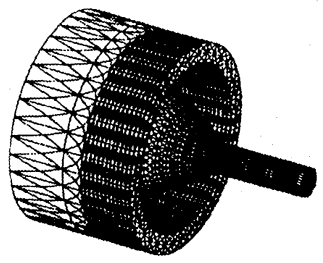

(c)

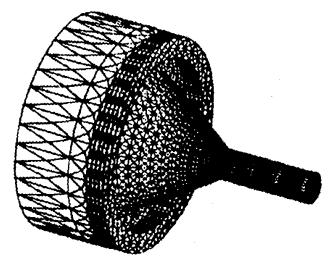

(b)

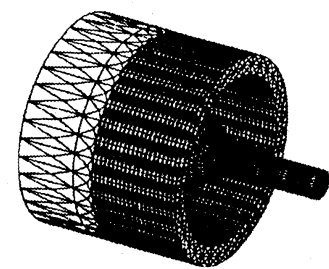

(d)
Fig. 3. Elements at typical overcoring stages.

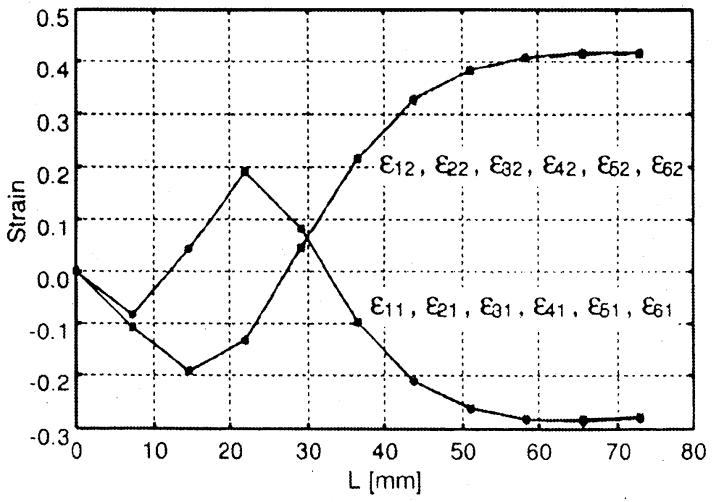

(a) Due to stress $\sigma_{11}^{\infty}=1$

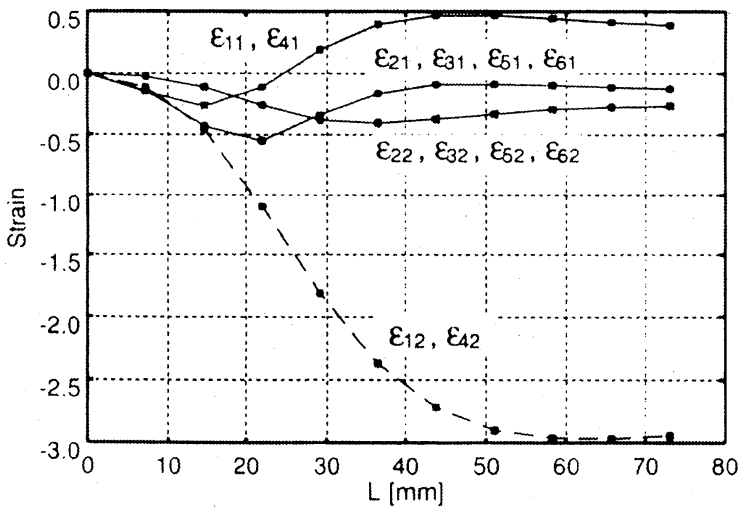

(b) Due to stress $\sigma_{22}^{\infty}=1$

Fig. 4. Induced strains by overcoring.

(1) 測定箇所にボーリング孔を掘削する.

(2) ボアホールカメラで岩の健全度を確認して, 大略 の測定箇所を選定する.

(3) 円錐孔底を整形する.

(4) 探査細孔を穿つ.

(5) ビデオイメージスコープを用いて探査細孔内の岩 の状態を詳細に観察する．特に，オーバーコアされる範 囲約 $10 \mathrm{~cm}$ 深さにわたってシームなどの弱面が存在しな いことを確認する.

（6）その結果に基づいて計測位置を確定する.

（7）整形した円錐孔底に，12 成分のひずみゲージを 埋設したひずみプラグ（Fig. 5 および 6 参照）をエボキ シ系樹脂で接着する.

(8) ひずみプラグ接着後 24 時間を経てオーバーコア リングを開始する.

（9）オーバーコアリングの進行過程で, 応力解放に伴 つて誘起される解放ひずみを断続的にいくつかのステー ジで計測記録する.

これらの基本的な手順は, 従来の応力解放法とほぼ同 じである. ${ }^{4)}$ も もちろん, 探査孔を観察した結果, 測定点 として不適格と判定された場合には, 円錐孔底を前進さ せて改めて整形し，上の手順により計測位置を確定した。

なお，ここで用いたひずみプラグは，既にFig. 2 にも 示したように, 円錐面の母線中央に $60^{\circ}$ 間隔の 6 点に母 線およびそれと垂直な方向に 2 成分, 合計 12 成分のひ ずみゲージを埋設したものである（Fig. 5 および 6 参 照).ひずみプラグの接着に際しては, ひずみゲージが所 


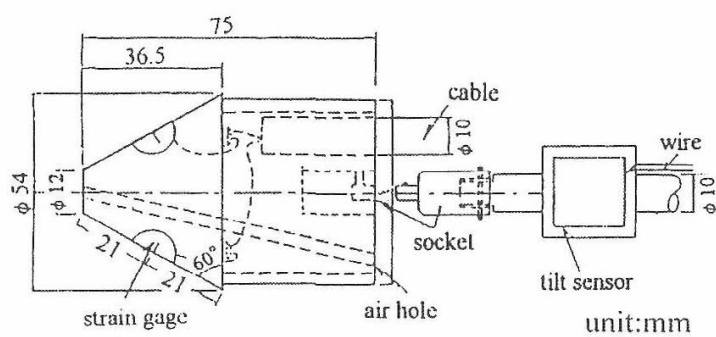

Fig. 5. Strain plug and tilt sensor.

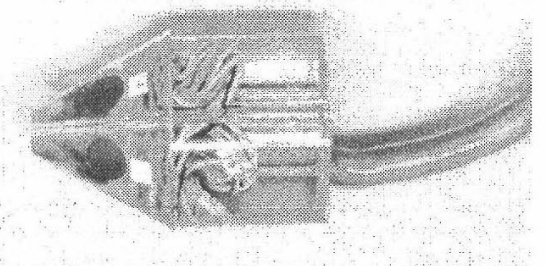

Fig. 6. Strain plug.

定の方向となるように，傾斜センサー（加速度計を利用） を用いて位置を確定した (Fig. 5 参照).

また，参考のために，Fig. 7 に, 左から順に，ボアホ 一ル穿孔およびオーバーコアリング兼用のビット，底面 平滑仕上げ用ビット，円錐孔底整形用ビットおよび探查 細孔用のビットを示した。

初期応力の測定は，2つのボアホールについて各々 2 位置で実施した。いずれも成功であった。探査細孔を用 いた探査のおかげである。また，同径オーバーコアリン グによれば，従来の大径（直径：20～25cm）の才ーバ ーコアリングに比べて, 掘削速度ははるかに速く, 労力 も軽減できる上，測定時間も短縮できた。厹ればかりで なく，同径オーバーコアリングでは，ボアホール壁がガ イドとなってオーバーコアリングの中心軸が孔底の円錐 の軸と完全に一致するので，偏心のない理想的なオーバ ーコアリンダができることも判明し，元の扔かげで応力 解放に伴うひずみの計測精度も向上するという余禄もあ つた。また，オーバーコアリング中に解放ひずみを断続 的に計測することよりに，測定時間を大幅に短縮するこ とができた。結論として，ここに加えた改良は現位置試 験では非常に有効であることが分かった。なお，現位置 測定の詳細については文献 ${ }^{15)}$ 見られたい。

以下に計測絬果を述べる。

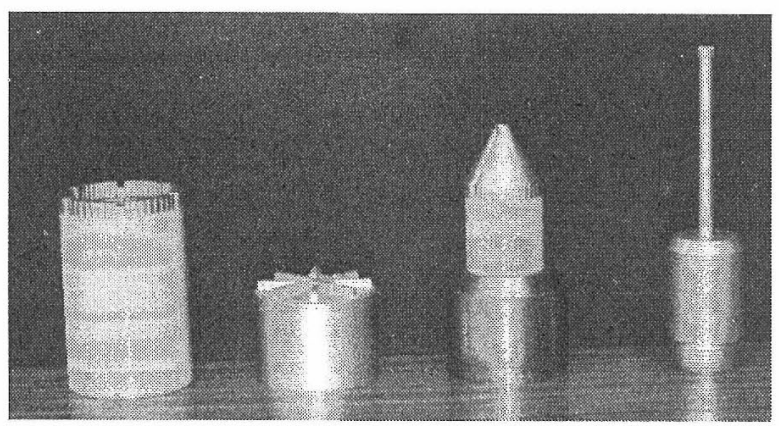

Fig. 7. Bits used for ImCEBM.
Fig. 8 は，オーバーコアリングの進行に伴って誘起さ れるひずみの変化の例を示したものである。ひずみは， シミュレーション結果から予測されたように，オーバー コアリング深度 (長) $L=10 \mathrm{~cm}$ ではほぼ収束している.

応力解放に伴うひずみが計測されると, 初期応力は式 （5）を用いて容易に求められる。測定結果をもとに推定 した初期応力の大きさと觉の方向は，只れ艺れ Table I およびFig. 9 に示した。なお，この灾力は，オーバーコ アリング深度 $L=13 \mathrm{~cm}$ でのひずみデータを用いて推定 したものである。もちろん，オーバーコアリング深度の 異なるいくつかのステージで計測したひずみデータに基 づいて推定すれば, 初期応力はより高い精度で求められ るであらう。推定した初期応力は相当異なっているよう にも見えるが，同じ岩質の 2 地点での推定結果はほぼ同 じであると見ることができるであろう。

なお，推定した初期応力の大きさは岩の弾性係数に比
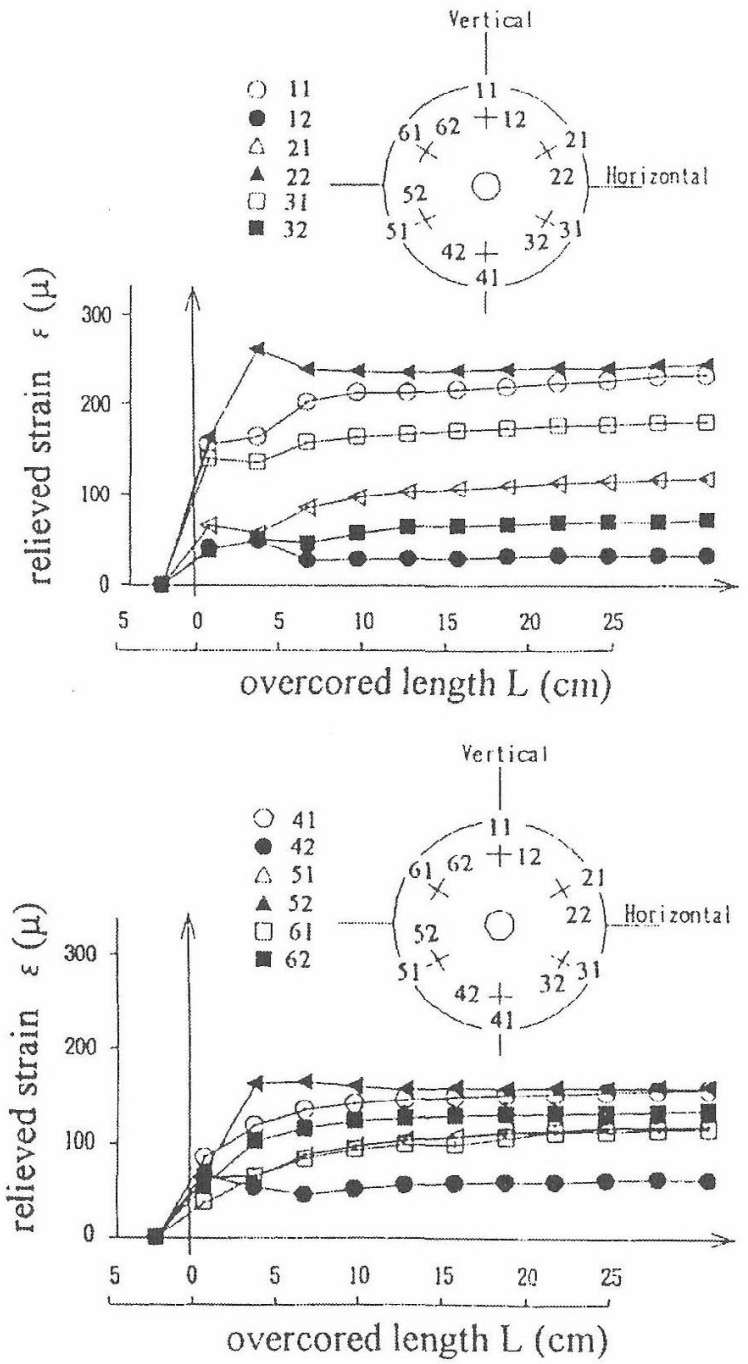

Fig. 8. Released strains by overcoring.

Table I. Principal initial stresses $(\mathrm{MPa})$.

$\begin{array}{clrrr}\text { Location } & \text { Rock } & \sigma_{1} & \sigma_{2} & \sigma_{3} \\ \text { no.1 } & \text { shale } & 21.4 & 8.1 & 2.2 \\ \text { no.2 } & \text { shale } & 17.8 & 7.2 & 3.8 \\ \text { no.3 } & \text { sandstone } & 36.5 & 12.3 & 7.8 \\ \text { no.4 } & \text { sandstone } & 37.8 & 12.2 & 7.0\end{array}$




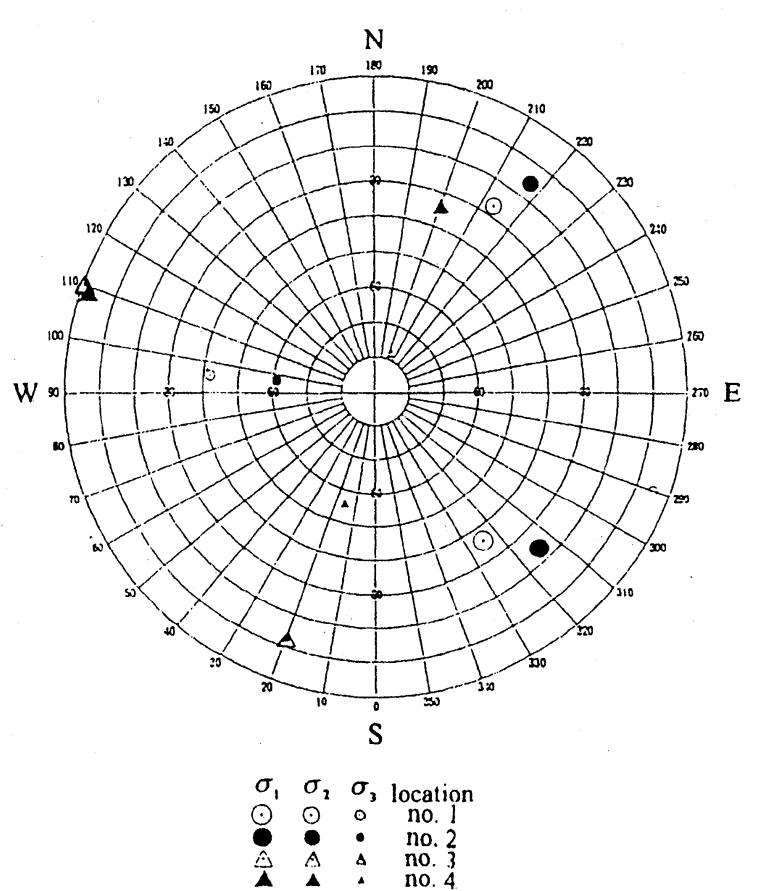

Fig. 9. Principal directions of initial stresses expressed in southern hemisphere.

例する (式 (5)参照) ので, 測定地点のボーリングコア を用いて弾性係数を正確に求めることが必要である.

\section{5 おわりに}

この論文では，改良円錐孔底法の概要とその適用性を 現位置試験で確認した結果について述べた。現位置試験 により，3つの改良，すなわち 1) 円錐孔底の先端に穿っ た探査細孔と，2) ボーリング孔と同径のオーバーコアリ ング，拉よび3)オーバーコアリング中での解法ひずみ計 測の有効性が示された。

また, 多重極境界要素法は複雑な形状の大容量のシミ ュレーション解析にも極めて有効であることも判明した。 このシミュレーション解析によって, 計測のための重要 な予備知識が得られ，また計算結果をもとに計測した解 放ひずみから初期応力を求めるための変換行列を得てい る.なお，この変換行列は，ここで示したモデルと幾何 学的に相似な形状の等方線形弾性体に対しては, Poisson 比が同じであれば，形の大小に拘わらず，もちろんその まま適用できる。

なお，ここでは改良円錐孔底法を地山初期応力の推定 に利用したが, この方法は掘削に伴う応力変化の測定な ど ${ }^{5)} に も$ 適用できることは言うまでもない.

さらに付け加えれば, 異方性弾性体に関しても, シミ ュレーション解析は可能であり, 変換行列を求めること もできるので, 異方性岩に関しても（初期）応力を推定 することも可能であろう。 また, エポキシ樹脂系の接着 剤は水中でも硬化するので, ひずみプラグを水中で接着 することも可能であろう.

改良点はまだ残されているであろうが，結論として， 改良円錐孔底法は高精度で, 廉価, 簡便でかつ省力化し た方法であると言えよう。多くの適用を期待したい.

現位置試験に際しては, 鏈山隆氏（関電興業(侏)）のご 協力を得た. 深く謝意を表したい.
1）土木学会, “初期地圧測定法の現状と課題”, 特に 2 および 6 章（1992）土木学会.

2 ) B. Amadei and O. Stephansson, "Rock Stress and Its Measurement”, Chapts. 3 and 5 (1997) Chapman \& Hall, London.

3 ) S. Kobayashi, N. Nishimura and K. Matsumoto, "Field Measurements in Geomechanics” (ed. S. Sakurai), p.1079 (1988) Balkema.

4）小林昭一, 西村直志, 吉川 太, 打田靖夫, 土木学会第 22 回岩盤力学に関するシンポジゥム講演論文集, 426 (1990).

$5)$ S. Kobayashi, T. Yoshikawa, T. Harada and Y. Uchita,. "Proc. of $7^{\text {th }}$ Intern. Congress on Rock Mechanics” (ed. W. Wittke), p.545 (1991) Balkema.

6 ) 小林昭一, 細田直文, 土木学会第 24 回岩盤力学に関する シンポジウム講演論文集，336（1992）.

7) Y. Obara and K. Sugawara, "Rock Stress" (eds. Y. Obara \& K. Sugawara), p.77 (1997) Balkema.

$8)$ S. Kobayashi, T. Takahashi, T. Yoshikawa and T. Yoshida, "Rock Mechanics -a Challenge for Society" (eds. P. Särkkä \& P. Eloranta ), p.109 (2001) Balkema.

9 ) 小林昭一, 高橋 徹, 吉川太, 吉田次男, 第 11 回岩の 力学国内シンポジウム講演論文集 (CD 版) A16 (2002).

10) 小林昭一編著, “波動解析と境界要素法”, 6章 (2000) 京 大出版会.

11) N. Nishimura, Appl. Mech. Rev., 55, 299 (2002).

12) N. Nishimura, K. Yoshida and S. Kobayashi, Eng. Anal. Boundary Elem., 23, 97 (1999).

13) Y. Saad and M. H. Schultz, SIAM J. Sci. Stat. Compt. ,7, 856 (1986).

14）高橋 徹, 小林昭一, 西村直志, 境界要素法論文集, 15, 105 (1998).

15）吉川太, 吉田次男, 鑓山 隆, 電力土木, No.285, 70 (2000).

Matrix [D] $(n=1 / 4)$

a) Overcored length at $\mathrm{L}=36.5[\mathrm{~mm}]$.

$\left[\begin{array}{rrrrrr}-1.799 & -0.023 & -1.807 & -0.058 & -1.801 & -0.062 \\ -0.147 & -0.198 & -0.198 & -0.025 & -0.198 & -0.025 \\ -0.216 & 0.038 & -0.166 & -0.143 & -0.166 & -0.143 \\ -0.002 & 0.000 & -0.542 & -0.122 & -0.543 & -0.122 \\ 0.000 & 0.000 & 0.058 & -0.205 & -0.059 & 0.205 \\ 0.628 & 0.142 & 0.314 & 0.070 & -0.310 & -0.070 \\ -1.800 & -0.047 & -1.812 & -0.015 & -1.820 & -0.012 \\ -0.147 & -0.201 & -0.199 & -0.020 & -0.200 & -0.020 \\ -0.216 & 0.036 & -0.167 & -0.138 & -0.167 & -0.138 \\ -0.001 & 0.000 & 0.540 & 0.122 & 0.540 & 0.122 \\ 0.000 & 0.000 & 0.058 & -0.205 & -0.059 & 0.205 \\ -0.623 & -0.141 & -0.309 & -0.070 & 0.315 & 0.070\end{array}\right]$

b) Overcored length at $\mathrm{L}=73[\mathrm{~mm}]$.

$\left[\begin{array}{rrrrrr}-0.622 & -0.020 & -0.625 & -0.023 & -0.624 & -0.024 \\ -0.094 & -0.165 & -0.121 & -0.031 & -0.121 & -0.031 \\ -0.129 & 0.015 & -0.104 & -0.121 & -0.104 & -0.121 \\ -0.001 & 0.000 & -0.540 & -0.093 & -0.541 & -0.093 \\ 0.000 & 0.000 & 0.030 & -0.156 & -0.030 & 0.156 \\ 0.624 & 0.108 & 0.312 & 0.053 & -0.311 & -0.053 \\ & & & & & \\ -0.522 & -0.022 & -0.626 & -0.019 & -0.626 & -0.018 \\ -0.094 & -0.166 & -0.121 & -0.030 & -0.121 & -0.030 \\ -0.129 & 0.015 & -0.104 & -0.120 & -0.104 & -0.120 \\ -0.001 & 0.000 & 0.539 & 0.093 & 0.540 & 0.093 \\ 0.000 & 0.000 & 0.030 & -0.156 & -0.030 & 0.156 \\ -0.623 & -0.108 & -0.310 & -0.053 & 0.312 & 0.053\end{array}\right]$

